\title{
Who Is Poor in the Czech Republic? The Changing Structure and Faces of Poverty after 1989*
}

\author{
JIŘí VEČERNÍK** \\ Institute of Sociology, Academy of Sciences of the Czech Republic, Prague
}

\begin{abstract}
The article provides a summary of evidence on the development of poverty in the Czech Republic since 1989. First, the new sources of poverty after 1989 and the new measures introduced to prevent or combat it are described. Second, the relative ease with which it is possible to leave the labour force and the impact of departures on household income is considered. Third, a variety of measurements that reveal different faces of poverty, comparing so-called objective and subjective indicators, are presented. Fourth, the working poor are examined and compared with the non-working poor. As a comparison of Microcensus data demonstrates, more change occurred in the composition than in the amount of poverty. Before 1989, poverty was caused mainly by demographic factors. In contrast, unemployment became the strongest factor of poverty under the market economy. This largely manifested itself after 1997, when there was a rapid increase in unemployment in the Czech Republic and the numbers for long-term unemployed grew even faster. Simultaneously, the problem of 'the working poor' appeared, but it is far less acute in the Czech Republic than in other EU countries. In conclusion, drawing sociology more into poverty research is stressed as a necessity.
\end{abstract}

Sociologický časopis/Czech Sociological Review, 2004, Vol. 40, No. 6: 807-833

Under the communist regime, various circumstances meant that poverty remained mostly invisible. First, ideology rendered it taboo, and all manifestations of poverty were deliberately concealed. Second, owing to the general equalisation of living conditions, disparities in income were quite small and the living standard of the majority of the population was not far from the minimum. Third, owing to compulsory employment, there was no poverty caused by labour market failures. In the end, by impoverishing and subordinating the entire population, the regime managed to conceal poor individuals and groups.

Since 1990, poverty issues have become a standard part of the agenda of so-

\footnotetext{
* This study was supported by the Targeted Grant Scheme of the Grant Agency of the Academy of Sciences of the Czech Republic No. S 7028351 under the title 'Structural Tensions in the Interface between the Labour Market and Social Policy from the Perspective of Human Resources and Social Inclusion'.

* Direct all correspondence to: Jiří Večerník, Institute of Sociology, Academy of Sciences of the Czech Republic, Jilská 1, 11000 Prague 1, Czech Republic, e-mail: Jiri.Vecernik@soc.cas.cz
} 
cial policy and research [Večerník 1991; Mareš 1999]. In comparison with advanced countries, knowledge in this area continues to be insufficient. An important impetus is the country's accession to the EU, which included it in the Lisbon process, oriented towards strengthening competitiveness and alleviating poverty. The Joint Memorandum on Social Inclusion in the Czech Republic [2003] identified the main problems and outlined policies to combat social exclusion. The National Action Plan on Social Inclusion [2004] gathered policies in various areas and set the course for 2004-2006.

There are a great many problems related to poverty definition and research. Basically, it is never possible to unambiguously establish the presence of poverty in a society. This is because need is not a state but a relation, which should have some permanence and which has many faces and references. It can be defined relative to a 'standard package' of goods and services, to the average income in society, or to various reference groups of the population, from the outer circle of, say, the most advanced countries, to the inner circle of a neighbourhood or a professional community.

One must distinguish, then, between poverty criteria (set from above) and poverty experience (gathered from below). There is a considerable mismatch between belonging to the category of the poor and really feeling poor. From above, the choice of poverty indicator is never unbiased: "a 'scientific' definition of poverty is a mirage; all definitions of poverty, ultimately, are political" [Barr 1994: 193]. The political status of the definition of poverty is, however, rarely made explicit or debated as such. In analysis, it is quite difficult to differentiate between purely 'academic' research and 'policy-oriented' research.

This article presents some evidence of the development of poverty in the Czech Republic. More change occurred in the composition than in the amount of poverty. While need was far from negligible before 1989, it was mainly caused by demographic factors and primarily affected the elderly and households with a large number of children. In contrast, under the market economy, unemployment became the strongest factor behind income insufficiency and poverty. This largely manifested itself after 1997, when there was a rapid increase in unemployment in the Czech Republic and the numbers of long-term unemployed grew even faster. Simultaneously, the problem of the 'working poor' also appeared.

The article is structured as follows. First, a description is made of the new sources of poverty after 1989 and the new measures introduced to prevent or combat it. Second, consideration is given to the relative ease with which a person can leave the labour force and the impact of these departures on household income. Third, a variety of measurements are presented that show the different faces of poverty, comparing so-called objective and subjective indicators. Fourth, attention is focused on the working poor and they are compared with the non-working poor. The article concludes with a discussion of informal sources and other 'hidden aspects' of the poverty story. 


\section{New situation, new policies}

The labour market that arose after 1989 became a new source of poverty. Unlike the mandatory employment and often life-long loyalty to one firm under the previous regime, in the new conditions many people were laid off, remained unemployed, or were forced to shift to lower paid jobs. In the first period of transition, frictions between labour demand and supply were in most cases resolved - otherwise the majority of job shifts were voluntary or through promotions. Self-employment and entrepreneurship, and new sectors and opportunities attracted active people. However, since 1997, unemployment has surfaced in full force.

From the outset of the transition, the government responded by introducing new measures or by reshaping or administrating old ones. Several measures were implemented to combat declining incomes and the risk of poverty.

Unemployment benefits (officially called 'material support for a jobseeker') were first established in 1990. At that time unemployment benefits were set for twelve months and at the level of 60 percent of the recipient's previous net wage (90 percent if the job loss was due to restructuring). This advantageous arrangement was withdrawn in 1991, and unemployment benefits were then set at the 65 percent level for the first six months and at 60 percent for the rest $(70$ percent during retraining). In 1992, the entitlement period was shortened to six months only, and unemployment benefits were set at the 60 percent level for the first three months and 50 percent for the rest.

Since October 1999, a job seeker can receive 50 percent of previous earnings during the first three months and 40 percent for the second three months (60 percent during retraining). The ceiling for financial support is higher, at 2.5 times the corresponding subsistence minimum in general (previously 1.5), and 2.8 times for jobseekers in retraining (previously 1.8). The new Act on Employment (in effect since October 2004) sets a longer period of unemployment benefits for persons aged 50-55 (9 months), and even longer for persons older than 55 years of age (12 months). For the second three-month period the benefit increases from 40 to 45 percent (50 percent for the first period).

The living minimum serves as the official poverty line, establishing the entitlement to request benefits up to a given level, set according to the size and composition of a household. It was established anew in 1991, but its principles have remained almost intact from the previous regime, i.e. it takes little account of the shared needs of households and of scale economies. Benefits calculated in this way are therefore advantageous to large households and disadvantageous to small families and single persons. Because the share of family expenditures on foodstuffs is declining and the share on housing rising, this imbalance is strengthening.

The minimum wage was first established in the Czech Republic in 1991 and was set at the level of $2000 \mathrm{CZK}$ (53 percent of the average wage). Soon after it was raised to $2200 \mathrm{CZK}$ and then remained frozen until 1996. Its long-term nominal stagnation and real fall was an escape from the dilemma faced by the governing 'liberals', who 
Table 1. Wage and benefits levels (CZK monthly and percentages)

\begin{tabular}{|c|c|c|c|c|c|c|c|c|c|c|c|}
\hline Indicator & 1990 & 1992 & 1994 & 1996 & 1998 & $\begin{array}{ll}1999 \\
* *\end{array}$ & $\begin{array}{l}2000 \\
* * \\
\end{array}$ & 2001 & 2002 & 2003 & $\begin{array}{l}1 \text { stQ } \\
2004\end{array}$ \\
\hline \multicolumn{12}{|l|}{ In CZK monthly: } \\
\hline Gross average wage & 3286 & 4644 & 6894 & 9676 & 11693 & 12666 & 13499 & 14640 & 15707 & 16917 & 16722 \\
\hline Net average wage & 2691 & 3715 & 5398 & 7538 & 9144 & 9931 & 10571 & 11465 & 12283 & 13057 & 12909 \\
\hline Gross minimum wage & 2000 & 2200 & 2200 & 2500 & 2650 & $\begin{array}{l}3250 \\
3600\end{array}$ & $\begin{array}{l}4000 \\
4500\end{array}$ & 5000 & 5700 & 6200 & 6700 \\
\hline Net minimum wage & $\mathrm{x}$ & $\mathrm{x}$ & $\mathrm{x}$ & $\mathrm{x}$ & $\mathrm{x}$ & $\begin{array}{l}2844 \\
3114\end{array}$ & $\begin{array}{l}3412 \\
3784\end{array}$ & 4194 & 4715 & 5087 & 5494 \\
\hline $\begin{array}{l}\text { Average } \\
\text { unemployment benefit }\end{array}$ & $\mathrm{x}$ & 1404 & 1839 & 2306 & 2335 & 2529 & 2781 & 2961 & 3164 & 3324 & 3480 \\
\hline $\begin{array}{l}\text { Living minimum } \\
\text { of a single adult }\end{array}$ & $\mathrm{x}$ & 1700 & 2160 & 2890 & 3430 & 3430 & 3770 & 4100 & 4100 & 4100 & 4100 \\
\hline $\begin{array}{l}\text { Living minimum } \\
\text { of a family of four } * * *\end{array}$ & $\mathrm{x}$ & 5450 & 6860 & 8810 & 9250 & 10060 & 10660 & 11420 & 11420 & 11420 & 11420 \\
\hline Average pension benefit & 1731 & 2413 & 3059 & 4613 & 5367 & 5724 & 5962 & 6352 & 6830 & 7071 & 7232 \\
\hline $\begin{array}{l}\text { Newly granted early } \\
\text { pension benefit - by } \\
\text { two years }\end{array}$ & $\mathrm{x}$ & $\mathrm{x}$ & $x$ & $\mathrm{x}$ & 5176 & 5370 & 5513 & 5837 & 5917 & & \\
\hline $\begin{array}{l}\text { Newly granted early } \\
\text { pension benefit - by } \\
\text { three years }\end{array}$ & $\mathrm{x}$ & $\mathrm{x}$ & $\mathrm{x}$ & $\mathrm{x}$ & 5406 & 5593 & 5659 & 5844 & 5667 & & \\
\hline \multicolumn{12}{|c|}{ Percentages of the net (gross) average wage:* } \\
\hline Minimum wage & 60.9 & 47.4 & 31.9 & 25.8 & 22.7 & $\begin{array}{l}25.7 \\
31.3\end{array}$ & $\begin{array}{l}29.6 \\
42.6\end{array}$ & 34.2 & 36.3 & 36.6 & 40.0 \\
\hline $\begin{array}{l}\text { Average } \\
\text { unemployment benefit }\end{array}$ & $\mathrm{x}$ & 37.8 & 34.1 & 30.6 & 25.5 & 25.5 & 26.3 & 25.8 & 25.8 & 25.5 & $\mathrm{x}$ \\
\hline $\begin{array}{l}\text { Living minimum } \\
\text { of a single adult }\end{array}$ & $\mathrm{x}$ & 45.8 & 40.0 & 38.3 & 37.5 & 34.5 & 35.7 & 35.8 & 33.4 & 31.4 & 31.8 \\
\hline $\begin{array}{l}\text { Living minimum } \\
\text { of a family of four }{ }^{* * *}\end{array}$ & $\mathrm{x}$ & 146.7 & 127.1 & 116.9 & 101.2 & 101.3 & 100.8 & 99.6 & 93.0 & 87.5 & 88.5 \\
\hline Average pension benefit & 64.3 & 65.0 & 56.7 & 61.2 & 58.7 & 57.6 & 56.4 & 55.4 & 55.6 & 54.2 & 56.2 \\
\hline $\begin{array}{l}\text { Newly granted early } \\
\text { pension benefit - by } \\
\text { two years }\end{array}$ & $x$ & $x$ & $x$ & $x$ & 56.6 & 54.1 & 52.2 & 50.9 & 48.2 & & \\
\hline $\begin{array}{l}\text { Newly granted early } \\
\text { pension benefit - by } \\
\text { three years }\end{array}$ & $\mathrm{x}$ & $\mathrm{x}$ & $\mathrm{x}$ & $\mathrm{x}$ & 59.1 & 56.3 & 53.5 & 51.0 & 46.1 & & \\
\hline $\begin{array}{l}\text { Net minimum wage in \% } \\
\text { living minimum of single }\end{array}$ & adult & $\mathrm{x}$ & $\mathrm{x}$ & $x$ & $\mathrm{x}$ & $\begin{array}{l}82.9 \\
90.8\end{array}$ & $\begin{array}{r}90.5 \\
100.4\end{array}$ & 102.3 & 115.0 & 124.1 & 134.0 \\
\hline
\end{tabular}

* Only the minimum wage is related to gross average wage, all other items are related to the estimated net wage. The estimate is made on family expenditures data by the Ministry of Labour and Social Affairs.

** In those years, the minimum wage was increased twice.

*** Two adults and two children 10-15 years old.

Sources: Statistical Yearbooks of the Czech Republic, Ministry of Labour and Social Affairs.

considered the minimum wage inappropriate for a free market economy, but who had to respect the already ratified international agreements that guaranteed its existence. When the Social Democrats came into office, the minimum wage started to rise again. It was only in January 2001 that it came to exceed the living minimum for a single adult, and it has continued to increase since. 
In Table 1 we provide an overview of various minimum levels and their changes over time. The minimum wage has started to improve its relative position, and since January 2004 it has been at the level of 6700 CZK (equal to 40 percent of the average wage). In 2001, it exceeded the amount for the living minimum for a single adult and is currently one-third higher. The replacement rate of the unemployment benefit has been decreasing steadily since it was introduced, and it now represents a mere one-quarter of the average wage. Pension benefits have maintained their relative weight since 2000, at about 55 percent of the average wage.

In fact, the guaranteed minimum wage, unemployment benefits, and the living minimum, together with benefits of state social support scheme and the minimum pension benefits (which is set higher than the living minimum), create quite a solid social safety net, and the Czech system thus ranks among the most advanced in Europe. Despite the fact that its social spending does not reach the relative level of some Western European countries, the poverty rate is among the lowest in the EU25.

The other side of the embracing safety net, protection in the temporary situation of job loss, is its welcoming effect for all those who give up - from the outset or after gathering gloomy experiences in the job search - on re-employment. Then, the state budget suffers from the rise in spending on unemployment and social benefits. There are adverse effects on employers, who suffer as a result of rising wages and related non-wage costs and from the reluctance of employees to take worse jobs. The voices calling for reconstruction of the system towards greater efficiency are getting stronger.

\section{Easy exits from the labour market}

In order to avoid unemployment status and/or ease the work burden, people - and the most vulnerable in particular - tend to leave precarious or poorly paid employment, either temporarily or permanently. Before 1989, state paternalism was accompanied by compulsory work, and departures from the labour force were regulated by law. Since 1990, job security has been unevenly distributed among the population, in accordance with people's education and skills, local opportunities, and employment availability. Employment behaviour is substantially affected by institutional conditions.

The state has proceeded inconsistently, keeping the newly settled minimum wage and unemployment benefits low, while providing easily accessible and higher social subsistence provisions. At the same time, easy exits from the labour force or employment have persisted or even been supported, such as early retirement. Specific 'coping strategies' are provided by the sick-leave system. In sum, there are a couple of basic methods used (and often misused) in order to get out of the active labour force:

1. Early retirement is not as widespread in the Czech Republic as in Hungary and (especially) in Poland, but nonetheless it is facilitated by a relatively favourable 
scheme. Two possibilities were introduced by the Pension Insurance Act in $1997 .{ }^{1}$ Permanently reduced early retirement can be taken by any worker after 25 years of pension insurance contributions, but no earlier than three years before legal retirement age. Temporarily reduced benefits are allowed solely for the long-term unemployed, also after 25 years of pension insurance contributions, but not earlier than two years before the legal retirement age. In either case, early retirees are not permitted to engage in any economic activity before reaching the legal retirement age.

Early retirement became very popular and its share in the number of pensions granted in recent years has grown steadily: 30 percent of all old-age pensions were in the form of early retirement in 1997, 48 percent in 1998, 52 percent in 1999 and nearly 60 percent in 2000 and 2001 (with only a small proportion of temporarily reduced early pensions). Early pension benefits granted in 2001 provided their beneficiaries with 90 percent of the full average pension. The mounting deficit for the pension bill triggered a government effort to alter the design of early retirement to make it less attractive. Consequently the share of early pensions out of all newly allotted pensions fell to 33 percent - which was probably also due to the fact that many of those interested in early retirement had already taken it, anticipating the introduction of stricter rules.

2. Disability pensions have been abundantly used and probably also misused. The number of disability pensions only began increasing in the early 1990s and since then it has become stable at 540000 (17 percent of all pension entitlements). Among all newly granted disability pensions, full pensions prevail: in 2001, 6600 new full disability pensions were granted in comparison with 3900 partial disability pensions. In 2001, the average level of full disability pension benefit was 97 percent of the full retirement benefit, while the partial disability pension benefit amounted to 61 percent. As of 1998, partially disabled persons are also entitled to claim the temporarily reduced early pension benefits.

3. Sick leave, though only a temporary exit, is also being used increasingly. While in 1990 the percentage of sick-leave days out of total working time was 4.8 percent, it increased to 6.7 percent in 2001; the average sick leave was 18 days in 1990, but by 2002 it had already reached 31 days. The relaxed (or sometimes even cooperative) attitude on the part of physicians and the minimal control executed by responsible bodies are what facilitate the taking of sick leave, which is used in particular by lower-wage categories to avoid work strain or, even, the risk of being laid off. Recently, the low ceiling of sickness benefits was increased, which makes them more advantageous for middle-wage categories of workers.

4. Welfare dependency is a welcome exit for not a large, but nevertheless a significant, category of the population. While among households headed by a person

\footnotetext{
1 As the introduction of the main change in the Pension Insurance Act - the gradual increase in the retirement age - evolved into a hot political debate and caused widespread aversion among trade unions (a mass demonstration - otherwise exceptional - was organised), the change was compensated with the introduction of easier conditions for early retirement.
} 
aged 55-59 only 25 percent have earned income of less than one-half of the total household income, this percentage steeply rises to 73 percent for the 60-64 age cohort and to 93 percent for the 65-69 cohort. The number of households that have earned income of at least one-quarter of the total household income is only 11 percent in the 60-64 cohort and 8 percent in the 65-69 cohort [Social Situation of Households 2001]. This is despite the fact that a later departure into retirement is rewarded with a 1.5 percent benefit increase for each 90 days of work.

Of the population aged 50-64 in 2001, 38.5 percent were already out of the labour force (28 percent of men and 48 percent of women). The main reason for the final separation of the labour force was leaving for retirement after reaching retirement age (45 percent of men and 62 percent of women), disability or sickness (34 percent of men and 16 percent of women), taking early retirement (11 percent of men and 9 percent of women) and reasons on the part of the employer - redundancy, the firm was shut down (7 percent of men and 9 percent of women). Other reasons, such as termination of a fixed-term contract, termination of a person's own business, or personal and family reasons were only cited rarely [Social Situation of Households 2001].

Therefore, the crucial task remains of making exits from employment more restricted and weakening their one-way flow by strengthening the incentives that will keep people in their jobs as long as possible or enable them to return to employment. This task rests on the shoulders of state administration and public policy, as well as employers and individuals. The dominant ideology of there being a fixed and early date for terminating working life, supported by a small difference between earned and social income for large sections of the population, must be transformed into motivation towards an open-ended career. One supportive measure to this end would be the removal of earning limits for pensioners.

In a certain sense, this is a legacy of the communist 'premature welfare state' [Kornai 1995: 131]. As work was compulsory for all, no unemployment trap or benefit dependency could appear. The welfare state was rooted in employment that often assumed the character of social security rather than real working tasks. At the same time, the shame attached to unemployment and rent-seeking behaviour, originally rooted in Czech middle-class society, largely disappeared during communist times. The massive abuse of the welfare system has thus since then been viewed as something deserved rather than something shameful.

Under pressure from deficitary public finances, the government is considering benefit reduction and some workfare measures. Specifically, the living minimum is to be lower and flatter, local governments are to have discretion in setting the concrete amount of benefits (acknowledging regional differences), and public works are to be compulsory for the long-term unemployed. The subsistence minimum as a fraction of the living minimum may even be applied to non-cooperative unemployed. Early or temporary exists of the labour force and activity might thus be hindered. 


\section{The different faces of poverty}

Poverty has many aspects and faces. Consequently, there are also many indicators and measurements of poverty. Research on poverty measurement is more than one hundred years old, and it continues to develop. For ten years now the Comparative Research Programme on Poverty (CROP), under the umbrella of the International Social Sciences Council, has been assembling hundreds of researchers around the world and providing information on related projects, events, and publications. The debate over poverty measurement was best summarised in the study 'Income Poverty in Advanced Countries' by M. Jäntti and S. Danziger [Atkinson and Bourguignon 2000: Chapter 6].

Combating poverty and social exclusion has become an important task of the EU. The Lisbon European Council in March 2000 established common objectives on poverty and social exclusion, which were then agreed by the Nice European Council in December 2000. National Action Plans on social inclusion have been prepared by member states and common indicators agreed on for monitoring progress towards common objectives and for encouraging mutual sharing of best experience. Following consideration devoted to the issue by experts in the field, the Laeken European Council in December 2001 endorsed the first set of 18 common statistical indicators for social inclusion [Atkinson, Cantillon, Marlier and Nolan 2002].

Czech statistics and the Czech government begun making use of the so-called Laeken indicators of poverty, along with the standard measurement by living minimum. A comparative analysis of indicators is, however, missing. Therefore, in this study I am continuing in my previous research [Večerník 1996 and 1998], and I also present some new data. In Table 2, the change over time of two basic indicators is displayed - according to the legal poverty line and the EU poverty line. I have also used the survey Social Conditions of Households, conducted following the Eurostat recommendations for matching information on persons and households and comparing 'objective' and 'subjective' indicators.

EU poverty. The poverty-risk rate has most recently been set at 60 percent of median equivalent income, where the first adult is calculated as 1.0, each additional adult as 0.5 , and each child up to 13 as 0.3 . The weight of both children and adults is thus lower than in the implicit equivalence scale used by the Czech living minimum calculation, while the burden of common household costs is higher. The implicit equivalence scale is thus quite flat.

Legal poverty. The Czech living minimum is composed of the amount of money required to meet a person's basic needs and the amount needed to meet household costs. The implicit equivalence scale of the calculation is very steep. Whereas household size elasticity is 0.8 in the calculation of the Czech official poverty line, it is about 0.4 in Belgium, the Netherlands, and Luxembourg, and about 0.5 in France and Spain [Večerník 1996]. ${ }^{2}$

${ }^{2}$ Within the restructuring of the benefit system a new calculation is planned, wherein instead of the current two-component calculation (the cumulated costs of each person and household) only costs of persons will be involved, with a separate housing benefit. 
Table 2. Households and persons at-risk of poverty by the legal and the EU poverty line and by family status 1988-2002 (percentages)

\begin{tabular}{lrrrrrrrr}
\hline Family status & \multicolumn{3}{c}{ Legal poverty line } & \multicolumn{5}{c}{ EU poverty line } \\
& 1988 & \multicolumn{1}{c}{1992} & 1996 & 2002 & 1988 & 1992 & 1996 & 2002 \\
\hline Households: & & & & & & & & \\
Couple with children & 1.1 & 3.4 & 2.7 & 4.4 & 1.1 & 3.2 & 5.8 & 7.3 \\
$\begin{array}{l}\text { One-parent with } \\
\text { children }\end{array}$ & 9.7 & 19.5 & 16.8 & 16.4 & 11.0 & 17.8 & 26.4 & 27.4 \\
One-person household & 13.5 & 1.4 & 1.0 & 2.5 & 45.5 & 4.0 & 5.3 & 9.9 \\
Other & 1.8 & 1.4 & 0.6 & 1.3 & 6.9 & 1.7 & 1.7 & 2.6 \\
Average & 4.5 & 2.7 & 2.1 & 3.3 & 13.7 & 3.3 & 5.0 & 7.2 \\
\hline Persons: & & & & & & & & \\
Couple with children & 1.3 & 3.7 & 3.2 & 4.8 & 1.4 & 4.0 & 7.5 & 8.9 \\
$\begin{array}{l}\text { One parent with } \\
\text { children }\end{array}$ & 10.7 & 21.1 & 18.6 & 16.8 & 12.0 & 21.2 & 29.8 & 31.5 \\
One-person household & 13.5 & 1.4 & 1.0 & 2.5 & 48.5 & 6.0 & 6.3 & 13.0 \\
Other & 1.5 & 1.6 & 0.7 & 1.4 & 7.0 & 2.2 & 2.1 & 3.1 \\
Average & 2.7 & 3.4 & 2.7 & 3.9 & 7.5 & 4.1 & 6.4 & 8.3 \\
\hline
\end{tabular}

Note: Legal poverty line: the percentage of households (persons) below the official living minimum.

EU poverty line: the percentage of households (persons) below the 60 percent median equivalent income (if the first adult is computed as 1.0, each other adult as 0.5 and each child as 0.3 ). Source: Microcensus 1988, 1992, 1996 and 2002, households files.

Calculating equivalent income using the same scale for various countries is a process freighted with problems, owing to the different consumption baskets, price structures, and advantages accorded to children or families, since all of these are expressed in different economies of scale. The advantage of a uniform scale, however, lies in its easy application and comparability.

If the EU equivalence scale is used, the poverty head count is twice as high as the living minimum measurement, while the share of pensioner households is even higher. ${ }^{3}$ Whereas the percentage of the official poor increases, the percentage of poor according to the EU measurement decreases slightly, and the composition of vulnerable categories changes substantially to the advantage of pensioners and to the disadvantage of families with children.

Subjective poverty. According to many authors, poverty is a feeling and not an objective situation, and families themselves should decide on the adequacy of their means to meet needs. There are various ways of measuring subjective poverty, all of which have their basis in respondents' declarations about their relative deprivation. Most methods were developed by the Dutch-Flemish econometric school and are based on respondents' estimates of the minimum level of income with which it is still possible to 'live decently'.

\footnotetext{
${ }^{3}$ Formally, no pensioner's household should be among the poor, according to the official threshold. This is because the minimum pension benefits slightly exceed the minimum income according to the living minimum.
} 
Figure 1. Household poverty according to SPL measurement (percentages)

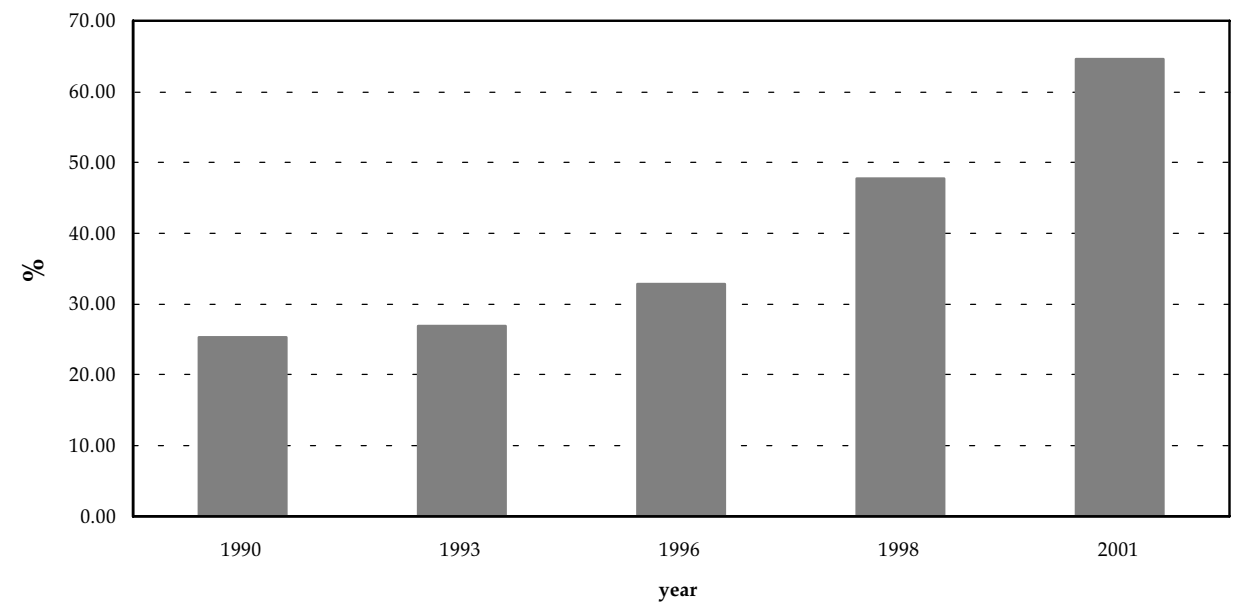

Source: Economic Expectations and Attitudes, December 1990, January 1993, January 1996 and April 1998; Social Situation of Households 2001.

One such method is the Subjective Poverty Line (SPL), which is derived from answers to the following question: 'What is the minimum amount of income that your family, in your circumstances, needs to make ends meet?' To derive the income standard, it is assumed that only households that are just able to balance their budget (i.e. that are on the brink of poverty) are able to give a useful estimate of what level of income correlates with a 'normal' standard of living [Deleeck and Van den Bosch 1992].

In the calculation of SPL, logarithms of Ymin (income estimated by the Minimum Income Question), $Y$ (current income of the household) and $f_{s}$ (size of the household) are calculated first. The log-linear relationship is then calculated as

$$
\ln Y \min =\beta 0+\beta 1 \ln f_{S}+\beta 2 \ln Y,
$$

and the poverty thresholds for each household size are calculated as

$$
Y \min =\exp [(\beta 0+\beta 1 \ln f s) /(1-\beta 2)] .
$$

In the mid-1990s I compared the Czech data with various poverty rates in seven EU countries and regions [Večerník 1996]. Whereas in socially generous countries, such as Belgium or the Netherlands, objective poverty amounted to 7 percent 
of households, and subjective poverty equalled between 10 and 20 percent, in southern countries without a developed social system objective poverty amounted to between 15 and 20 percent and subjective poverty between 30 and 40 percent. In the Czech Republic, objective poverty was the lowest, while subjective poverty was on a level higher than that of Belgium.

Since then subjective poverty has increased steadily and significantly in the Czech Republic. In 1998 it surpassed the level of Greece, and in 2001 it reached an unbelievable 65 percent of the general population (Figure 1). Whereas in the early 1990s the relation of subjective poverty lines to the average household income was about 75 percent, the perceived minimum income was, on average, higher than the declared current income. ${ }^{4}$ This suggests that the budget standard perceived by Czechs is more a reflection of the consumption level of advanced Western countries than the conditions in the home country.

There are several possible reasons why these percentages are high. First, the amount of basic needs is exaggerated, as the 'minimum amount' includes an expanding number of goods and services. Second, the declared actual income is underestimated, as people tend to declare only formal income and do not mention informal, secondary, and supplementary income. Third, the method considers the minimum too generously. In fact, there is only a very small reduction of the declared minimum income using the above-mentioned method. Nevertheless, when comparing the figures over time, the central message remains - a rapidly rising 'minimum budget'.

In contrast with the very steep equivalence scale implicit in social legislation, the equivalence scale in people's minds is very flat. This generally reflects the finding by Buhman et al. [1988] regarding the considerable difference between 'programme' and 'subjective' scales. It means that households see themselves much more as economic actors and budgetary units by stressing common needs and costs, while the calculation of the officially established living minimums see them much more as a sum of individual members with only low shared costs. Consequently, households with more members are advantaged and smaller households disadvantaged.

Feeling poor. Unlike the concept of poverty as an income insufficiency, perceived poverty is always a relational characteristic, dependent on the social environment, the uneven pace of real change, and subjective expectations, etc. Low incomes can be purely transitional, without necessarily reflecting financial problems as a poverty status. In the Economic Expectations and Attitudes surveys (1990-1998), a question was posed 'Do you feel your household is poor?' which returned the answer 'definitely yes' (out of four variants) in about 8 percent of cases.

\footnotetext{
${ }^{4}$ I took this surprising result and consulted with one of the founding fathers of the 'subjective poverty school', Bernard M.S. van Praag. He admitted that the method returns quite high figures but was also surprised by the result. Unfortunately, comparative figures are missing, though the Czech survey was designed according to Eurostat recommendations and in anticipation of the new EU-SILC (EU Statistics on Income and Living Conditions).
} 
Table 3. Various measurements of poverty risk by type of household (percentages)

\begin{tabular}{|c|c|c|c|c|c|}
\hline \multirow[t]{2}{*}{ Type of household } & EU & $\begin{array}{l}\text { Living } \\
\text { minimum }\end{array}$ & SPL & Feel poor & \multirow{2}{*}{$\begin{array}{c}\text { People } \\
\text { around are } \\
\text { better-off } \\
5\end{array}$} \\
\hline & 1 & 2 & 3 & 4 & \\
\hline Single, under 65 & 4.7 & 2.5 & 41.7 & 16.9 & 9.3 \\
\hline Single, over 65 & 14.1 & 5.3 & 75.5 & 24.5 & 10.6 \\
\hline Couple, both under 65 & 9.6 & 0.0 & 98.6 & 27.0 & 13.1 \\
\hline Couple, at least one over 65 & 2.0 & 0.7 & 44.6 & 12.0 & 7.9 \\
\hline Couple with one child & 1.2 & 0.4 & 87.1 & 15.1 & 10.8 \\
\hline Couple with two children & 4.3 & 2.6 & 48.5 & 10.7 & 6.6 \\
\hline Couple with three or more children & 4.9 & 3.4 & 66.8 & 10.6 & 6.5 \\
\hline $\begin{array}{l}\text { Couple with at least one child and other } \\
\text { members }\end{array}$ & 13.6 & 10.3 & 86.4 & 22.4 & 10.3 \\
\hline Single-parent family & 6.2 & 4.5 & 48.8 & 16.5 & 8.2 \\
\hline Other & 21.5 & 16.4 & 82.1 & 26.9 & 12.5 \\
\hline Total & 5.8 & 3.1 & 59.6 & 16.0 & 8.9 \\
\hline
\end{tabular}

Note: While indicators 1-3 are based on the information about households, indicators 4-5 are based on what the person reported. To enable their combination, the household data were assigned to each person. Unlike Table 1, the unit of observation here is an adult person (16 years and older) and thus the data slightly differ.

Source: Social Situation of Households 2001, persons and households files merged.

In 2001, a similar question was posed in the statistical survey on the Social Situation of Households, with only three variants (poor, not poor-not rich, rich). The resulting poverty head count is twice as high, whether as a result of the fewer available response variants or the actual worsening of the situation in the view of households over time (column 4 in Table 3). Another question asked whether respondents consider the other people around them as belonging to the same, a higher, or a lower social class (with the variant 'don't know' for the rest). We can assume that if people perceive the people around them as belonging to a higher class, this is an indication of social exclusion (column 5 in Table 3).

We gathered five poverty measurements on one sample of individuals for further analysis, each of which is based on a different kind of information and gives specific results. The question then arises of how far they overlap, or, conversely, how much they address different faces of poverty. The analysis (Table 4) shows that:

- about one-quarter of adult persons are poor according to at least one measurement;

- while Legal and EU poverty fit well together (Pearson correlation coefficient 0.7), all other indicators are weakly associated (Pearson correlation coefficients below $0.2)$;

- 70 percent of poor adult persons are poor according to one indicator only, which most frequently is the 'feeling poor' indicator;

- about one-fifth of poor adult persons are poor according to two indicators, the most frequent indicators being 'feeling poor' and 'worse-off than people around'. 
Table 4. Simultaneous incidence of poverty risk by various measurements (percentages)

\begin{tabular}{|c|c|c|c|c|c|c|}
\hline $\begin{array}{l}\text { Persons living in poor } \\
\text { households according to } \\
\text { measurement }\end{array}$ & $\begin{array}{c}\text { Percentage } \\
\text { of cases }\end{array}$ & $\begin{array}{c}\mathrm{EU} \\
1\end{array}$ & $\begin{array}{l}\text { Living } \\
\text { minimum } \\
\quad 2\end{array}$ & $\begin{array}{l}\text { SPL } \\
\text { reduced* } \\
3\end{array}$ & Feel poor & $\begin{array}{c}\text { People } \\
\text { around are } \\
\text { better-off } \\
5\end{array}$ \\
\hline Not poor by any indicator & 75.5 & - & - & - & - & - \\
\hline Poor by one indicator & 16.9 & 5.6 & 0.1 & 0.0 & 62.9 & 31.4 \\
\hline Poor by two indicators & 4.3 & 37.2 & 12.7 & 9.0 & 76.0 & 65.6 \\
\hline Poor by three indicators & 1.9 & 100.0 & 68.4 & 72.7 & 45.2 & 13.5 \\
\hline Poor by four indicators & 1.1 & 100.0 & 85.6 & 95.6 & 93.3 & 25.6 \\
\hline Poor by five indicators & 0.3 & 100.0 & 100.0 & 100.0 & 100.0 & 100.0 \\
\hline Total & 100.0 & 5.8 & 3.1 & 3.1 & 16.0 & 8.9 \\
\hline
\end{tabular}

* The SPL poverty was reduced by a calculation of only 40 percent of the amount required as the minimum income.

Source: Social Situation of Households 2001, persons and households files merged.

Besides income poverty there are various other deprivation indexes based on information on housing and possession of durable goods. One of the most recent attempts applied also to CEE data (the Czech Republic, Hungary and Slovenia) determined four indicators of deprivation (deprived in basic needs, in secondary needs, in accommodation standards, and in subjective income satisfaction). Next, the authors combined deprivation indices with income insufficiency and constructed an index of 'consistent poverty'. Finally they proposed combining the universal European absolute minimum set for non-income items with the national relative income standard [Förster, Tarcali and Till 2002; Förster, Fuchs, Immervoll and Tarcali 2003].

Another attempt was made in the Eurostat survey using national data for the new EU member and candidate countries. For the sake of exploratory analysis, several durable goods were chosen, with special attention given to the 'enforced lack' of durable goods (i.e. when the person wishes to acquire a given item but cannot afford it). This is a preparatory step to establishing the new statistical base of the EU, where a common core set of deprivation items will be collected, including questions on the enforced lack of some durable items, housing deterioration, the capacity to afford holidays or decent food, the capacity to face unexpected financial expenses, arrears on some payments, the ability to keep the home adequately warm, and other indicators [Guio 2004]. ${ }^{5}$

The other indicators of satisfaction and income deprivation here return ambiguous results (Table 5). Only about one-half of the persons belonging to poor households measured by monetary indicators (EU, Legal, SPL) actually feel poor, and even fewer are dissatisfied with household finance. If we match indicators ap-

\footnotetext{
${ }^{5}$ Instead of the European Community Household Panel, stopped after the 2001 wave, a new statistical instrument, the EU Statistics on Income and Living Conditions (EU-SILC) is to become the new EU reference source for comparative statistics on income distribution and social exclusion at the European level.
} 
Table 5. Monetary and subjective measurements of poverty risk (percentages)

\begin{tabular}{lcccccc}
\hline $\begin{array}{l}\text { Persons living in poor } \\
\text { households according to } \\
\text { measurement }\end{array}$ & $\begin{array}{c}\text { Feel poor } \\
1\end{array}$ & $\begin{array}{c}\text { People } \\
\text { around are } \\
\text { better-off } \\
2\end{array}$ & $\begin{array}{c}1 \text { and } 2 \\
\text { together }\end{array}$ & $\begin{array}{c}\text { Dissatisfied } \\
\text { **with } \\
\text { house-hold } \\
\text { finance } \\
3\end{array}$ & $\begin{array}{c}\text { Dissatisfied } \\
\text { *with } \\
\text { housing } \\
4\end{array}$ & $\begin{array}{c}3 \text { and } 4 \\
\text { together }\end{array}$ \\
\hline 1. EU & 48.2 & 10.3 & 14.2 & 44.3 & 15.4 & 18.8 \\
2. Living minimum & 51.5 & 12.1 & 16.0 & 45.6 & 14.1 & 13.4 \\
3. SPL reduced & 53.1 & 14.2 & 18.9 & 40.7 & 14.0 & 10.8 \\
\hline
\end{tabular}

* We took the lowest variant of answers of six possible (between 'fully satisfied' and 'fully dissatisfied').

** The SPL poverty was reduced by a calculation of only 40 percent of the amount required as the minimum income.

Source: Social Situation of Households 2001, persons and households files merged.

Table 6. 'Getting by' statements correlated with poverty risk by various measurements (percentages)

\begin{tabular}{|c|c|c|c|c|c|c|c|}
\hline $\begin{array}{l}\text { How the household } \\
\text { gets by on its } \\
\text { finance }\end{array}$ & Frequency & $\mathrm{EU}$ & $\begin{array}{l}\text { Living } \\
\text { minimum }\end{array}$ & $\begin{array}{c}\text { SPL } \\
\text { reduced }^{* *}\end{array}$ & Feel poor & $\begin{array}{c}\text { People } \\
\text { around are } \\
\text { better-off }\end{array}$ & $\begin{array}{l}\text { Dissatis- } \\
\text { fied }^{*} \text { with } \\
\text { household } \\
\text { finance }\end{array}$ \\
\hline with great difficulty & 15.0 & 20.5 & 12.7 & 13.7 & 43.4 & 15.2 & 41.3 \\
\hline with difficulty & 25.8 & 6.3 & 3.0 & 5.5 & 21.8 & 11.2 & 12.2 \\
\hline with minor difficulty & 38.3 & 2.2 & 0.9 & 2.4 & 8.2 & 7.1 & 3.6 \\
\hline rather easily & 15.7 & 1.0 & 0.3 & 1.5 & 3.3 & 5.2 & 2.0 \\
\hline easily & 4.2 & 1.1 & 0.0 & 1.4 & 3.7 & 3.7 & 2.6 \\
\hline very easily & 0.9 & 0.0 & 0.0 & 0.0 & 2.7 & 5.3 & 0.0 \\
\hline Total & 100.0 & 5.8 & 3.1 & 4.7 & 16.0 & 8.9 & 11.1 \\
\hline
\end{tabular}

* We took the lowest variant of the responses of the six possible responses (between 'completely satisfied' and 'completely dissatisfied').

** The SPL poverty was reduced by a calculation of only 40 percent of the amount required as the minimum income.

Source: Social Situation of Households 2001, persons and households files merged.

proximating social exclusion (columns 1 and 2 in Table 5 combined), only about 15 percent of EU or legally poor are affected. A similar result is returned through a combination of simultaneous dissatisfaction with household finance and housing (columns 3 and 4 in Table 5 combined).

Another measurement exercise is enabled through the use of a common 'subjective poverty' question: 'How does your household get by on the finance you have?' (Table 6). Here, the explanatory potential of the individual poverty measurements appears to be much better. Indeed, 88 percent of people living under the le- 
Table 7. Poverty risk by various measurements correlated with various income concepts (correlation coefficients)

\begin{tabular}{|c|c|c|c|c|c|c|c|}
\hline \multirow[b]{2}{*}{$\begin{array}{l}\text { Persons living in poor } \\
\text { households according to } \\
\text { measurement }\end{array}$} & \multirow[b]{2}{*}{$\begin{array}{l}\text { Total } \\
\text { disposable } \\
\text { income }\end{array}$} & \multirow[b]{2}{*}{$\begin{array}{l}\text { Net market } \\
\text { income }\end{array}$} & \multirow[b]{2}{*}{$\begin{array}{l}\text { Net } \\
\text { transfer } \\
\text { income }\end{array}$} & \multicolumn{4}{|c|}{ Income per } \\
\hline & & & & capita & $\begin{array}{c}\text { EU } \\
\text { equivalent } \\
\text { unit }\end{array}$ & $\begin{array}{l}\text { square } \\
\text { root unit }\end{array}$ & $\begin{array}{c}\text { living } \\
\text { minimun } \\
\text { scale }\end{array}$ \\
\hline EU & -0.23 & -0.21 & 0.00 & -0.22 & -0.25 & -0.25 & -0.01 \\
\hline Living minimum & -0.16 & -0.15 & 0.00 & -0.18 & -0.19 & -0.19 & 0.07 \\
\hline SPL reduced* & -0.24 & -0.22 & 0.00 & -0.16 & -0.22 & -0.23 & -0.18 \\
\hline Feel poor & -0.19 & -0.21 & 0.11 & -0.16 & -0.19 & -0.19 & -0.06 \\
\hline People around are better-off & -0.08 & -0.10 & 0.07 & -0.06 & -0.08 & -0.08 & -0.04 \\
\hline $\begin{array}{l}\text { Dissatisfied with household } \\
\text { finance }^{* *}\end{array}$ & -0.13 & -0.13 & 0.03 & -0.16 & -0.16 & -0.15 & 0.06 \\
\hline $\begin{array}{l}\text { Great difficulties getting by } \\
\text { on household finance }\end{array}$ & -0.17 & -0.17 & 0.01 & -0.20 & -0.21 & -0.20 & 0.07 \\
\hline
\end{tabular}

* The SPL poverty was reduced by a calculation of only 40 percent of the amount required as the minimum income.

** We took the lowest variant of answers of six possible (between 'completely satisfied' and 'completely dissatisfied').

Source: Social Situation of Households 2001, persons and households files merged.

gal poverty line and 82 percent of people living under the EU poverty line declare financial difficulties. A question then arises: why do people who claim to have small financial difficulties feel themselves to be poor? Hardly any reason can be found among the available explanatory variables - the only particular feature we can identify is the positive correlation to transfer income among those households, which could refer to a stigmatising effect arising from social benefits.

Last but not least, we turn to the eternal question: what is the 'best' income indicator for measuring the welfare of households? There are numerous variants of ways to adjust disposable household income to the size and composition of a family, and therefore the scholarly debate over equivalence scales has lasted for decades. Here, we can test empirically which income indicators best fit one or another of the methods of poverty measurement (Table 7). Surprisingly, the differences between the three most frequently used indicators - income per capita, per EU (modified OECD) equivalence unit, and per square root unit - are almost negligible. So, they can be substituted for one another. The EU poverty indicator exhibits the strongest association with the most income indicators.

\section{Preventing poverty by redistribution or by employment}

As we have demonstrated, what occurred after 1989 was an important shift away from 'old poverty', which was produced by specific stages in the life cycle (that of the elderly in particular), towards 'new poverty', resulting from labour market fail- 
ures. In income terms, while poverty previously referred to insufficient transfer income, currently an important source of poverty - if not increasingly the main one is low earnings. This also has consequences for the politics of poverty alleviation instead of the standard channels of income equalisation through redistribution, what is necessary is the introduction of better income packaging through employment participation.

Redistribution through taxes and transfers probably remains the main tool for alleviating poverty anyway. As a comparison of selected OECD countries showed, more than one-third of the population in some countries would, hypothetically, be living in poverty if there were no redistribution. In the Czech Republic the figure would be one-fifth, given the still small gap between low incomes and the average. This is similar to the situation in other countries, such as Germany, the Netherlands, and Denmark, where wage bargaining takes place, which has an equalising effect on the distribution of market income. State redistribution generally reduces poverty by 5-15 percent; the Czech figure is the lowest [Förster 2000; Večerník 2002].

The transfer of money is only a temporarily efficient measure, as no new resources are generated and the work motivation of people eventually declines owing to their reliance on state support. As the dependency rate has risen steadily in advanced countries, the effort has been to reduce it and to 'make work pay'. It is necessary to place the emphasis on activation policies, i.e. making social benefits depend on the activity of the unemployed (searching for a job, training and re-training, taking temporary jobs). Firms also need to become more interested in job creation and retention. "Employment should be financially rewarding for workers, but it also needs to be affordable for employers" [OECD 2003: 114].

Adjustments to both the supply and demand sides of support for employment are also a concern for the Czech Republic. In terms of net replacement rates the country ranks among the most generous European countries. The net replacement rate of wages by social benefits is as high as in the most generous European countries, where social benefits can fully replace the average earnings of a production worker with a family [OECD 2004]. Despite the fact that the differences between average wage and subsistence benefits have become smaller (see Table 1), the gap between the guaranteed social minimum and wages of the less skilled workers have created a relatively inviting poverty trap, which has diminished in recent years as the living minimum has frozen (Figure 2). ${ }^{6}$

Given the quite generous social security scheme, the reservation wage of the long-term unemployed remains close to the economy's average wage. The problem is that the bulk of the long-term unemployed suffer from low qualifications and poor employability. This state of affairs is mainly advantageous for Roma families, where the number of children is usually high and employability low. Furthermore, this trap is similarly appealing to rural households, where living costs are low due

${ }^{6}$ The living minimum has remained stable because of very low inflation. The legal conditions for its increase have thus not been met. 
Figure 2. Wage and benefits levels (CZK monthly)

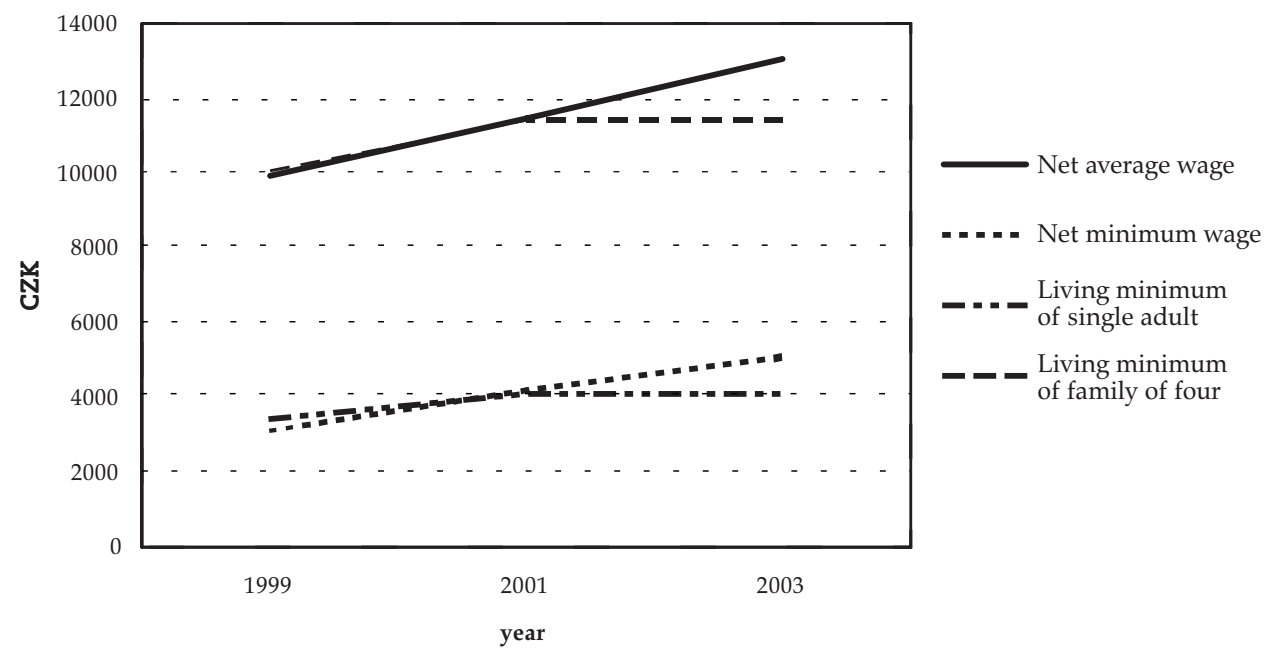

to considerable income in kind, while expenditures connected with employment are high due to greater transportation costs.

Minimum wage. A simple remedy is to administratively hold wages above the level of social benefits. In 1999 the government began making an effort to resolve the inconsistency between a low minimum wage and higher subsistence benefits by setting the minimum wage higher. By January 2001 the dominance of the minimum wage over the subsistence minimum for a single person had been achieved, and this has continued even further (see Table 1). The motivational function of the minimum wage is, however, questionable, on both the supply and the demand sides of labour.

On the supply side, and taking into account the circumstances of the formal economy alone, the difference between low wages and welfare payments are still not a sufficient stimulus when all the costs related to work, including its pain and strain, are taken into account. Despite the fact that the relative level of the minimum wage is currently 34 percentage points above the living minimum for a single person, each family headed by a minimum-wage earner needs contributions through social benefits, unless more active earners are present.

On the demand side, this has also has created a series of adverse effects: it raises the costs of unskilled work above the market price. As a result, employers are reluctant to hire less-skilled workers and try to replace them with technology or, more often, undemanding illegal workers (usually Ukrainians). Moreover, the minimum wage is frequently declared as the official payment of employees who are compensated by employers with unregistered remuneration, too, particularly in the services and catering sectors. 
As there are no statistics for minimum wage recipients (wage surveys do not cover firms with less than 20 employees, which is where the minimum wage is most often applied), there is room for speculation on its real impact. Estimates refer to about 1-2 percent of employees, but in fact probably no one works for such a low amount. Once the amount increases substantially, payroll tax rises, too, which has an adverse effect on formal employment: either employers maintain the job but as fully informal, or they reduce or cease the activity and dismiss the employee altogether.

According to a study based on individual data in France, raising the minimum wage has a clearly negative effect on the employment of low-paid workers. With a rise of 10 percent, the probability of a male employee losing his job increases by 13 percent, and by 10 percent for a female employee. While the effect was zero for young workers (up to 25 years), it increased significantly for older workers [Kramarz and Margolis 1999].

The fact that an increase in the minimum wage could have an adverse effect on employment was also demonstrated in a study on Hungary. Kertesi and Köllö [2004] concluded from their empirical analysis that the Hungarian decision to increase the minimum wage by 57 percent in 2001 represented a loss of employment opportunities. Although the situation in large firms remained the same, the sector of small firms lost about 3 percent of its jobs in less than a year, while the job retention and job finding potential of low-wage workers deteriorated. Depressed regions were more severely affected despite possessing more favourable conditions for achieving a positive effect.

Activation policies. The direct opposite to administrative intervention in the labour market is the direction that emphasises the enhancement of work flexibility through the development of broad skills and multitask occupations, flexible contracts and hours, and the adaptability of the workplace and related commuting or migration. Unlike the lively debate that has been taking place on workfare and other labour activation measures in Western Europe [Lind and Hornemann Möller 1999], there has not yet been much discussion about the flexibility of the labour force in the Czech Republic.

The government's opinion has only recently changed. The Ministry of Labour and Social Affairs estimates that approximately 140000 people prefer welfare status over employment activity. The Labour Minister has declared a readiness to take any measure aimed at ensuring benefits are better targeted and abuses minimised. A good example of this is the recent restrictions on sickness benefits, which has led to their significant reduction. Other restrictions are in the pipeline.

But the current situation is rather one of ambivalence. On the one hand, the rules for receiving unemployment benefits are strict. Any person who refuses to take a suitable job or undergo a medical examination, or who refuses to cooperate with the labour office (attending regular consultations or complying with the conditions of the Individual Action Plan) must be de-registered. On the other hand, the enforcement of rules is weak and informal avenues are frequently employed. There 
Table 8. Factors of poverty risk by various measurements (standardised regression coefficients)

\begin{tabular}{llccccccc}
\hline $\begin{array}{l}\text { Persons living in } \\
\text { poor households } \\
\text { according to } \\
\text { measurement }\end{array}$ & $\begin{array}{l}\text { Number } \\
\text { of active } \\
\text { earners }\end{array}$ & $\begin{array}{c}\text { Number } \\
\text { of children }\end{array}$ & $\begin{array}{c}\text { Number } \\
\text { of un- } \\
\text { employed }\end{array}$ & $\begin{array}{c}\text { Education } \\
\text { of the } \\
\text { household } \\
\text { head }\end{array}$ & $\begin{array}{c}\text { Labour } \\
\text { income }\end{array}$ & $\begin{array}{c}\text { Pension } \\
\text { benefits }\end{array}$ & $\begin{array}{c}\text { Other } \\
\text { social } \\
\text { benefits }\end{array}$ & $\mathrm{R}^{2}$ \\
\hline EU & -0.13 & 0.09 & 0.21 & -0.04 & -0.21 & -0.20 & -0.07 & 0.14 \\
Living minimum & -0.05 & 0.15 & 0.24 & -0.02 & -0.17 & -0.12 & -0.05 & 0.11 \\
SPL reduced* & -0.26 & -0.02 & 0.09 & -0.07 & -0.12 & -0.25 & -0.11 & 0.11 \\
Feel poor & -0.07 & -0.02 & 0.13 & -0.09 & -0.14 & -0.08 & 0.08 & 0.09 \\
$\begin{array}{l}\text { People around } \\
\text { are better-off }\end{array}$ & -0.05 & 0.00 & 0.01 & -0.05 & -0.05 & -0.00 & 0.03 & 0.02 \\
\hline
\end{tabular}

Note: Regression results are only preliminary as all explanatory variables were included as ordinal variables.

All coefficients are significant at the 0.000 level except those in italics.

* The SPL poverty was reduced by a calculation of only 40 percent of the amount required as the minimum income.

Source: Social Situation of Households 2001, persons and households files merged.

are various practices in use that make it possible to receive benefits and work informally at the same time. ${ }^{7}$

The system needs to be restructured. The Conception of Public Finance Reform (June 2003) requires benefits to be better targeted. It proposes withdrawing the social allowance and has re-set the housing allowance. It criticises the fact that under the new administrative arrangements poverty relief benefits are paid by local authorities, which take no interest in efficiency measures. They receive relevant funds from the state, but otherwise have no capacity to consider individual cases, as the current Act on Material Need prescribes. Systemic and organisational changes regarding the division of tasks between the state and the localities are thus necessary.

The main task, however, is to alleviate poverty by means of redistribution (transfer income) to a lesser extent, and instead to do more to prevent it by means employment (earned income). In other words, keep redistribution to tackle the 'old' poverty (derived from the life cycle) and do the maximum to reduce the 'new' poverty (induced by the labour market). Analysis should respond to such questions as what the relative impact of various factors on poverty is and how employment and earned income affect vulnerability. A specific issue is the trapping effect that the actual benefits/wages replacement rate has on people's behaviour.

\footnotetext{
${ }^{7}$ Moreover, it has received new legal encouragement - e.g. the new Act on Employment (in effect since October 2004) introduces the possibility of engaging in paid activity while receiving unemployment benefits (up to half the minimum wage). Therefore, benefit recipients can easily combine an official part-time job with unofficial work paid in cash, with no chance of any checks.
} 
Table 9. Poverty risk among non-pensioner households by the number of active earners, children and unemployed persons (percentages)

\begin{tabular}{|c|c|c|c|c|c|c|c|c|c|}
\hline \multirow{4}{*}{$\begin{array}{l}\text { Persons living in } \\
\text { poor households } \\
\text { according to } \\
\text { measurement }\end{array}$} & \multicolumn{9}{|c|}{ Number of active earners } \\
\hline & \multirow[t]{3}{*}{ None } & \multicolumn{4}{|c|}{ One } & \multicolumn{4}{|c|}{ Two or more } \\
\hline & & \multicolumn{2}{|c|}{ No or one child } & \multicolumn{2}{|c|}{$\begin{array}{c}\text { Two or more } \\
\text { children }\end{array}$} & \multicolumn{2}{|c|}{ No or one child } & \multicolumn{2}{|c|}{$\begin{array}{l}\text { Two or more } \\
\text { children }\end{array}$} \\
\hline & & No UN & UN & No UN & UN & No UN & UN & No UN & UN \\
\hline$\overline{E U}$ & 46.6 & 5.5 & 14.2 & 9.5 & 30.8 & 0.9 & 5.6 & 2.5 & 0.0 \\
\hline Living minimum & 33.2 & 1.9 & 7.7 & 7.0 & 26.7 & 0.5 & 3.0 & 1.2 & 0.0 \\
\hline SPL reduced* & 36.4 & 4.3 & 6.0 & 4.4 & 20.0 & 0.3 & 0.7 & 0.6 & 0.0 \\
\hline Feel poor & 52.4 & 12.3 & 36.8 & 15.3 & 29.5 & 8.9 & 19.1 & 9.1 & 8.7 \\
\hline $\begin{array}{l}\text { People around are } \\
\text { better-off }\end{array}$ & 13.8 & 7.9 & 16.4 & 10.5 & 8.6 & 5.9 & 4.9 & 6.7 & 4.3 \\
\hline
\end{tabular}

$\mathrm{UN}=$ unemployed persons.

Note: Only households with no pensioner are included.

Source: Social Situation of Households 2001, persons and households file merged.

In Table 8, individual measurements of poverty are regressed to various characteristics of households and/or adult persons. The explanatory power of household characteristics is evidently quite weak; altogether they explain only about 10 percent of the variance, with the exception of EU poverty (14 percent variance explained). The age of the head of the household and the size of the locality were excluded from the final analysis as having only negligible relevance. The strongest predictors are the numbers of unemployed, active earners, and dependent children.

A more specific look into the exposure of households of non-pensioners to poverty, based on those three main factors, is provided in Table 9. Here we find three interesting results:

- unemployment is the dominant factor behind poverty in its manifold profiles, even if family income is above the living minimum and the family burden is low;

- unemployment together with the burden of a family (two or more children) makes people poor according to all measurements;

- feeling poor produces the greatest differences with regard to other poverty measurements in almost all categories of households.

Another set of results stems from the inspection of income sources through a simple division between labour income and transfer income among non-pensioner households, as indicated in Table 10:

- while monetary measurements identify households where labour and transfer income are more or less equal, the subjectively poor are much more often people who live primarily off of work;

- the poor according to monetary measurements receive one-fifth of the labour income of the non-poor and between 2 and 2.5 times more transfer income; 
Table 10. Income sources among non-pensioner, at-risk of poverty households and their distance from the non-poor (percentages)

\begin{tabular}{lcccccc}
\hline $\begin{array}{l}\text { Persons living in poor } \\
\text { households according to } \\
\text { measurement }\end{array}$ & \multicolumn{3}{c}{ Composition of household income } & \multicolumn{3}{c}{ Income of the poor in \% of non-poor } \\
\cline { 2 - 7 } & $\begin{array}{c}\text { Labour } \\
\text { income }\end{array}$ & $\begin{array}{c}\text { Social } \\
\text { benefits }\end{array}$ & Total & $\begin{array}{c}\text { Labour } \\
\text { income }\end{array}$ & $\begin{array}{c}\text { Social } \\
\text { benefits }\end{array}$ & Total \\
\hline EU & 57.8 & 40.4 & 100.0 & 22.2 & 229.9 & 34.8 \\
Living minimum & 52.0 & 45.7 & 100.0 & 19.6 & 246.4 & 34.1 \\
SPL reduced* & 47.3 & 49.7 & 100.0 & 14.8 & 219.2 & 28.3 \\
Feel poor & 79.7 & 17.8 & 100.0 & 59.1 & 211.9 & 67.7 \\
People around are better-off & 86.4 & 10.6 & 100.0 & 79.4 & 133.6 & 82.9 \\
\hline
\end{tabular}

Note: Only households with no pensioner are included.

Source: Social Situation of Households 2001, persons and households files merged.

Table 11. Income per equivalent unit and poverty risk by legal and EU poverty line (percentages)

\begin{tabular}{lcccccccrr}
\hline \multirow{2}{*}{$\begin{array}{l}\text { Number } \\
\text { of children }\end{array}$} & \multicolumn{3}{c}{ Income gap $^{*}$} & \multicolumn{3}{c}{ Legal poverty percentage } & \multicolumn{3}{c}{ EU poverty percentage } \\
\cline { 2 - 10 } & UN & $\begin{array}{c}\text { First } \\
5 \%\end{array}$ & $\begin{array}{c}\text { Second } \\
5 \%\end{array}$ & UN & $\begin{array}{r}\text { First } \\
5 \%\end{array}$ & $\begin{array}{c}\text { Second } \\
5 \%\end{array}$ & UN & $\begin{array}{c}\text { First } \\
5 \%\end{array}$ & $\begin{array}{c}\text { Second } \\
5 \%\end{array}$ \\
\hline No & 32.0 & 20.4 & 15.4 & 10.1 & 0.0 & 1.2 & 25.0 & 6.4 & 1.8 \\
One & 43.8 & 30.3 & 26.8 & 23.7 & 5.3 & 4.3 & 38.8 & 16.0 & 11.1 \\
Two & 46.8 & 32.5 & 29.3 & 29.4 & 3.8 & 7.3 & 45.5 & 5.2 & 7.3 \\
Three & 54.8 & 37.7 & 32.5 & 32.3 & 14.4 & 0.0 & 51.7 & 19.0 & 0.0 \\
Total & 39.5 & 25.9 & 20.8 & 18.9 & 2.6 & 3.0 & 34.4 & 8.9 & 4.9 \\
\hline
\end{tabular}

Note: Only adult persons employees or the unemployed are included. The equivalent unit is computed as in EU poverty: the first adult is calculated as 1.0, each additional adult as 0.5, and each child up to 13 as 0.3 .

$\mathrm{UN}=$ unemployed persons

First $5 \%=$ employees with earnings in the 1st vintile of the distribution of earnings.

Second $5 \%=$ employees with earnings in the 2nd vintile of the distribution of earnings.

* The overall average (persons in the labour force) of the income per equivalent unit minus the corresponding income in the category.

Source: Microcensus 2002, persons and households files merged.

- the total income of the poor by monetary measurements is only one-third of the income of non-poor households; however, it is much higher in the case of subjective measurements.

Microcensus 2002 provides another look at the vulnerability of low-wage categories in comparison with the unemployed. Unlike the Social Situation of Households survey, where only data on household income are available, Microcensus provides detailed information also about personal income. Thus we can define individuals ac- 
Table 12. Distribution of poverty risk among the unemployed, low-wage earners, and other employed persons (percentages)

\begin{tabular}{lrccccccccc}
\hline \multirow{2}{*}{$\begin{array}{l}\text { Number } \\
\text { of children }\end{array}$} & \multicolumn{4}{c}{ Legal poverty percentage } & \multicolumn{4}{c}{ EU poverty percentage } \\
\cline { 2 - 12 } & UN & $\begin{array}{c}\text { First } \\
5 \%\end{array}$ & $\begin{array}{c}\text { Second } \\
5 \%\end{array}$ & $\begin{array}{c}\text { All } \\
\text { other }\end{array}$ & Total & UN & $\begin{array}{c}\text { First } \\
5 \%\end{array}$ & $\begin{array}{c}\text { Second } \\
5 \%\end{array}$ & $\begin{array}{c}\text { All } \\
\text { other }\end{array}$ & Total \\
\hline No & 20.0 & 0.0 & 1.1 & 1.4 & 22.5 & 25.2 & 2.7 & 0.8 & 2.5 & 31.2 \\
One & 27.9 & 1.9 & 1.5 & 4.2 & 35.5 & 23.3 & 2.9 & 2.0 & 4.8 & 33.0 \\
Two & 24.9 & 1.2 & 2.2 & 3.1 & 31.4 & 19.6 & 0.8 & 1.1 & 5.9 & 27.5 \\
Three & 7.1 & 1.0 & 0.0 & 2.5 & 10.5 & 5.9 & 0.7 & 0.0 & 1.8 & 8.3 \\
Total & 79.9 & 4.2 & 4.7 & 11.2 & 100.0 & 74.0 & 7.1 & 3.9 & 15.0 & 100.0 \\
\hline
\end{tabular}

See the notes below Table 11.

Source: Microcensus 2002, persons and households file merged.

cording their personal earnings and ascribe to them household characteristics such as equivalent income or poverty exposure. In Table 11, the unemployed with employees are compared with a wage within the first or second vintile (each 5 percent of income receivers) of the distribution of earnings. In sum, this is the bottom decile of active earners that could be most exposed to poverty. ${ }^{8}$ The results indicate the following:

- income gaps between the unemployed and the first two vintiles of the employed are considerable - 15 and 20 percent on average; the gaps increase with the number of children;

- near one-fifth (in the case of legal poverty) and more than one-third (in the case of EU poverty) of the unemployed are poor in comparison with the much lower figures among the low-wage employed - their poverty rates do not fall away from the national averages;

- while poverty rises considerably and monotonously by the number of children in the case of the unemployed, this is not necessarily the case for low-wage employees.

Finally, we can observe the degree of dispersion of legal poverty and the risk of poverty among the most vulnerable groups, i.e. the unemployed and the lowest two vintiles of employees. In Table 12, the percentages of the total of those in the labour force (i.e. not including the self-employed or non-active persons) are displayed and show the following:

- 85-90 percent of poor employees or the unemployed are concentrated in the three categories and 75-80 percent in the sole category of the unemployed;

8 This definition of low-paid workers is stricter than the usual definition used by the OECD, which sets the threshold at two-thirds of the earnings median. Instead of 10 percent as in our calculation, low-paid workers would make up 15 percent in the Czech Republic, a figure thus located in the middle of the developed OECD countries (OECD 2001). 
- regarding the number of children, families with three or more children represent only a very small portion of the poverty stock due to their minor occurrence among the population; in contrast, the unemployed living in childless households make up 20-25 percent;

- when the two criteria are combined, the change to the poverty stock differs only slightly in relation to poverty measurement: according to the legal poverty line, mostly one and two-child families are included here; according to the EU poverty line, childless households are also important.

In this analysis, we left out self-employed persons. The reason is that we believe they tend to underestimate their actual income even more than employees do, which makes the results less reliable and not comparable. In fact, more of the selfemployed than employees fall below the poverty lines, whether the legal or EU measurement. This otherwise corresponds to EU statistics, where a risk of poverty is reported by 6 percent of employees, 14 percent of the self-employed, and 39 percent of unemployed persons, as the EU average (without Greece). In Portugal and Spain, but also Austria and Sweden, the gap is even greater [Working Poor 2004]. Comparative data for the Czech Republic return 2 percent for employees, 6 percent for the self-employed and 34 percent for the unemployed. ${ }^{9}$

There are, then, not many working poor in the country and the risk of poverty is much higher among unemployed persons than among low-wage recipients. The gap between percentages of non-working and working poor is also much larger in comparison with EU countries. There are at least two reasons for this: wage disparities increased considerably after 1989, but the relative position of lowest categories was maintained [Večerník 2001]; and unemployment benefits are quite low, even in comparison with low wages and also with the social benefits from state social support. However, one must profess some doubts about the data, given the fact that thus far supplementary earnings to unemployment benefits have been forbidden. Whether or not they actually exist, they have certainly never been declared.

\section{Conclusion}

Poverty is a multi-faceted and multi-dimensional phenomenon, which cannot be described with one indicator but only through a bundle of them. Here, I have surveyed poverty in the Czech Republic through four alternative indications. While legal poverty and the standard EU indicators report poverty at about 3-7 percent of households, the declaration of perceived poverty is established at 16 percent of households, while the Subjective Poverty Line (SPL) returns an immense poverty rate that is close to 60 percent.

In monetary poverty (i.e. the legal and the EU measurement), the Czech Republic is at one-half of the EU-15 average and close to the EU countries with the

${ }_{9}$ Using the official poverty line, the figures are halved in each case. 
most generous social systems, such as Belgium, the Netherlands, or the Scandinavian countries. In comparison with the other new EU member countries the advantage is even greater: the figure for Hungary is 10 percent, for Poland 15 percent, for the Baltic countries between 15 and 20 percent, and for Slovakia even slightly above 20 percent [Guio 2004].

While so many countries saw a rapid increase in poverty during the transition, monetary poverty has changed its face rather than its rate in the Czech Republic. Although before 1990 poverty affected mostly the elderly (single-pensioner households), their share in the figure has sunk close to zero according to the legal measurement or to one-quarter of the original figure in the EU scale. Instead, the percentage of poor families has quadrupled and the percentage of single-parent families has also increased significantly. Simply put, the social security system protects better and more reliably against poverty than the labour market.

In subjective terms the situation is different. There are people of active age, even working, who feel poor, despite their decent income. The reason for this could be either the extraordinary expenditures of the family budget - connected with new housing or equipment, adolescent children's studies, etc. - or, at the opposite end, a sudden fall in income not below the poverty line but below the level adequate to meet set requirements. In contrast, one-half of people considered poor according to the legal or EU measurement do not feel subjectively poor, which means that income insufficiency is not necessarily perceived in terms of poverty.

Evidently the main source of poverty in the Czech Republic - as elsewhere in advanced countries - is unemployment. The labour market is thus the main battlefield in this area. It clearly means that all possible strategies of activation and making work pay should be put forward, while simultaneously tightening the channels to social benefits and conditioning corresponding entitlements. This is the master plan recommended by the EU, the OECD, and other organisations, and applied in the most advanced Western countries in various ways. The recent plans of the Czech government indicate that future efforts are moving in this direction.

Despite satisfactory figures on poverty, we should bear in mind that the transition itself exposed people to the threat of poverty. Although poverty in the narrow sense remains limited, vulnerability to poverty is still high, and people are sometimes forced to mobilise various measures in order to avoid serious financial problems, some of which are on the brink of 'acceptable behaviour'. Some households do not pay rent, many families do not modernise their apartments, most of them severely economise even on basic consumption. The practices of informal and selfhelp activities developed during the communist period also surfaced during the transition.

A massive surge in social exclusion is not likely. Poverty remains mostly an economic characteristic rather than a social stratification category. Little social exclusion has been encountered in the Czech Republic so far, unlike ethnic and lifestyle-related exclusion, which affect the Roma population and especially Roma newcomers from Slovakia. Their non-adherence to common work habits and their spe- 
cific way of life precludes acceptance by the majority population. At the same time, the problem of 'imported exclusion' has also emerged, specifically with regard to immigrants from the former USSR and the Balkan countries.

In any case, what is positive is that poverty has become a public problem. The social inclusion process, developed by the EU, is a big challenge for tackling and monitoring poverty. In view of this, Czech poverty research still suffers from several problems:

First, it is not easy to provide current representative data on poverty owing to rapid changes in income composition and distribution. Earnings, household incomes, consumption, and employment status of individual family members are monitored simultaneously only in the Family Expenditures Surveys, which are not however representative. The Microcensus surveys, which provide the most complex source of information, have become only occasional - while the usual time interval between individual surveys was four years, it recently changed to six years.

Second, poverty is a minority problem after all, and it moreover comprises various specific types. There are various reasons why large-scale surveys cannot portray the nuances of poverty: the sample size, the coverage of lowest-status and minority groups and of the population living in institutions..$^{10}$ Qualitative sociological and anthropological methods, focusing on research and participatory observation concerning marginalised or vulnerable groups, are needed here.

Third, poverty is always relative and subjective in the end. Not only poverty itself, but also the context is thus important. Not only the objective circumstances but also the 'soft' public climate matter in its perception and for the endorsement of policies for its alleviation. This is related to such terms as 'social justice', 'social equality' and 'equal chances', and newly also 'social cohesion' and 'social inclusion'. The internal consistency and the external legitimacy of these terms might significantly ease the inclusion process.

Although every step beyond elementary statistics produces immense problems of data availability and cross-national comparability, bringing more sociology into poverty research makes the picture more realistic. This also involves getting more information 'from below' about the real functioning of institutions in the economic behaviour of people - such as the minimum wage, state social support, and social assistance benefits. Participatory observation is the main tool for distinguishing between the poor who are really in need and those who are not, and for revealing the real coping strategies of people.

With regard to indicators, we should also think about indicators other than 'performance' or 'output'. For policies, the relationship between 'input' and 'output'

\footnotetext{
${ }^{10}$ Let us note the fact that statistical income surveys are collected using even smaller samples, decreased from 2 percent to 0.25 of the targeted (but not reached) households. Although results are adjusted with various procedures, the basic bias - the missing extremes of income distribution - can hardly be rectified. Regarding coverage, the Roma population - and its lowest strata in particular - is probably heavily underestimated in statistical surveys.
} 
indicators is crucial, i.e. relationship between costs and results, as it measures the efficiency of the process. Such a comparison can provide different results depending on the temporal perspective: short-term success in alleviating poverty by transfers can turn into failure in the long run, if welfare dependency is produced by the original policy. What matters in the end is real empowerment through skills and self-reliance - values that are not easy to catch and measure.

JIŘÍ VEČERNíK focuses mainly on the labour market, social policy, and economic inequality under transition, and recently also on the institutional and value background of the postcommunist transformation. He collaborates with the ILO, OECD and the European Commission. His most recent publications are 'Social Policies and Structures under Transition: Social Cohesion and Latent Conflicts' (Prague Economic Papers, forthcoming) and 'Skating on Thin Ice: A Comparison of Work Values and Job Satisfaction in CEE and EU Countries' (International Journal for Comparative Sociology, forthcoming).

\section{References}

Atkinson T., B. Cantillon, E. Marlier and B. Nolan. 2002. Social Indicators: The EU and Social Inclusion. Oxford University Press.

Atkinson, A.B. and F. Bourguignon (eds.) 2000. Handbook of Income Distribution. Volume 1. Amsterdam: Elsevier.

Barr, N. (ed.) 1994. Labor Markets and Social Policy in Central and Eastern Europe. The Transition and Beyond. Oxford University Press.

Concept for the Reform of Public Finance. 2003. Prague: Ministry of Finance (internal document).

Förster, M.F., G. Tarcali and M. Till. 2002. "Income and Non-Income Poverty in Europe: What Is the Minimum Acceptable Standard in an Enlarged European Union?" IARIW conference paper.

Förster, M. F., M., Fuchs, H. Immervoll and G. Tarcali. 2003. "Social Inclusion in Larger Europe: All About Money?" Pp. 11-38 in Understanding Social Inclusion in a Larger Europe: Open Debate. Eurosocial Vienna 71.

Guio, A.-C. 2004. "The Laeken Indicators: Some Results and Methodological Issues in Acceding and Candidate Countries" (Eurostat, internal document).

Joint Memorandum on Social Inclusion in the Czech Republic. 2003. Ministry of Labour and Social Affairs of the Czech Republic.

Kertesi, G. and J. Köllö. 2004. “Fighting ‘Low Equilibria' by Doubling the Minimum Wage? Hungary's Experiment". The William Davidson Institute Working Paper \# 644.

Kramarz, F. and D.N. Margolis. 1999. "Salaire minimum et emploi en France et aux ÉtatsUnis". Pp. 128-131 in Données sociales, edition 1999. Paris: INSEE.

Lind, J. and I. Hornemann Möller. 1999. Inclusion and Exclusion: Unemployment and NonStandard Employment in Europe. Aldershot: Ashgate.

Mareš, P. 1999. Sociologie nerovnosti a chudoby. (The Sociology of Inequality and Poverty) Prague: Slon.

National Action Plan on Social Inclusion. 2004. Ministry of Labour and Social Affairs of the Czech Republic. 
OECD 2001. Society at a Glance. OECD Social Indicators. Paris: OECD.

OECD 2003. Employment Outlook. Toward More and Better Jobs. Paris: OECD.

OECD 2004. Taxing Wages. Paris: OECD.

Večerník, J. 1996. Markets and People. The Czech Reform Experience in a Comparative Perspective. Aldershot: Avebury.

Večerník, J. 1998. Občan a tržní ekonomika. Přijmy, nerovnost a politické postoje v české společnosti. (The Citizen and the Market Economy. Income, Inequality, and Political Attitudes in Czech Society) Prague: Nakladatelství Lidové noviny.

Večerník, J. 1999. "The Middle Classes in the Czech Reforms: The Interplay between Policies and Social Stratification." Communist and Post-Communist Studies 32: 397-416.

Večerník, J. 2001. Earnings Disparities in the Czech Republic: Evidence of the Past Decade and Cross-national Comparison. Prague Economic Papers 10: 201-222.

Večerník, J. 2002. "Income Redistribution via Taxes and Benefits in the CR: Change and Perception after 1989." Czech Journal of Economics and Finance 52: 4-22. Printed version in Czech, English version at: http://www.financeauver.org.

Working Poor in the European Union 2004. European Foundation for the Improvement of Living and Working Conditions. Luxembourg: European Communities.

\section{Data sources}

\section{Microcensus surveys}

This article draw on: the 1989 Microcensus conducted by the Czech Statistical Office (CSO) on a 2 percent random sample $(\mathrm{N}=69,912)$ in March 1989, which includes annual income for 1988; the 1992 Microcensus, conducted by the CSO on a 0.5 percent random sample $(\mathrm{N}=16,234)$ in March 1993, which includes annual income for 1992; the 1996 Microcensus conducted by the CSO on a 1 percent random sample $(\mathrm{N}=28,148)$ in March 1997, which includes annual income for 1996; and the $2002 \mathrm{Mi}-$ crocensus conducted on 0.25 percent random sample $(\mathrm{N}=7,678)$ in March 2003 and including annual income for 2002.

\section{Social Situation of Households}

A survey conducted by the CSO in May-June 2001 on a sample of 10870 households (re-weighted for the entire population). In each household, each adult person was investigated. Besides household characteristics and income, people were also asked about various opinions on employment and family well-being.

\section{Economic Expectations and Attitudes (EEA)}

These surveys of the Czechoslovak and later only the Czech population started in May 1990 and were conducted biannually in 1990-1992 and annually in the following years (1993-1998). The samples include adults selected by a two-step quota sampling procedure, whereby the region and size of the locality were defined in the first step, and gender, age and education in the second. The data was collected by the Centre for Empirical Research STEM. 